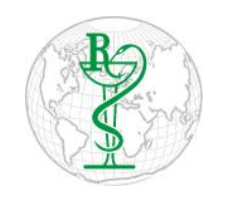

INDO GLOBAL JOURNAL OF

PHARMACEUTICAL SCIENCES

ISSN 2249- 1023

\title{
A Comparative Study between Aqueous and Ethanolic Extracts of Allium Odorum Linn with Reference to its Antioxidant and Alpha- Amylase Inhibition Activities
}

\author{
Nayan Talukdar ${ }^{1 *}$, Rujita Devi ${ }^{1}$, Indrani Barman ${ }^{2}$ \\ ${ }^{1}$ Programme of Biotechnology, Faculty of Science, Assam down town University, Guwahati, Assam-781026, India \\ ${ }^{2}$ Programme of Biochemistry, Faculty of Science, Assam down town University, Guwahati, Assam-781026, India
}

Address for Correspondence: Nayan Talukdar, Nayan.new16@gmail.com

Received:
13.04.2020
Accepted:
26.11.2020
Published:
30.03.2021
Keywords
Allium odorum,
phytochemical
screening, $\alpha-$
amylase
inhibition
activity,
antioxidant
activity.

Received:

13.04.2020

Accepted:

26.11.2020

30.03.2021

Keywords

Allium odorum

screening, $\alpha$

amylase

inhibition

\begin{abstract}
Allium odorum Linn belongs to the family Liliaceae which is established as a potent medicinal plant in folkware medicinal system. The plant is native to China as well as Japan and also cultivated in North-east part of India as an essential part of culinary. In this study, leaves of this plant were collected from Imphal East district of Manipur and extracted in water and ethanol. The extracts were screened for the presence of various bioactive compounds and its inhibition activity against $\alpha$-amylase. Both aqueous and ethanol extracts showed presence of bioactive compounds like sterol, tannin, saponin, di-terpines and sugars whereas bioactive compounds like flavonoid, glycoside, and amino acids were present only in ethanol extracts. Major bioactive compound like alkaloid test showed negative result during the study. The sample was also found to exhibit a maximum of $89.27 \%$ and $69.79 \%$ of $\alpha$-amylase inhibition activity in ethanol and water extract respectively. When sample was subjected to its antioxidant activity it exhibited $84.85 \%$ and $65.88 \%$ by DPPH method and a maximum of $67.73 \%$ and $57.97 \%$ by $\mathrm{H}_{2} \mathrm{O}_{2}$ method in ethanol and water extract respectively. Hence, from this study the sample can be used as a potential source for anti-oxidant and antidiabetic agent which will help us to substitute some commercially available synthetic drugs near future. () 2020 iGlobal Research and Publishing Foundation. All rights reserved.
\end{abstract}

Cite this article as: Talukdar, N.; Devi, R.; Barman, I. A Comparative Study between Aqueous and Ethanolic Extracts of Allium Odorum Linn with Reference to its Antioxidant and Alpha-Amylase Inhibition Activities. Indo Global J. Pharm. Sci., 2021; 11(1): 56-61. DOI: http://doi.org/10.35652/IGJPS.2021.111008 .

\section{INTRODUCTION}

Medicinal plants play an important role in human health. Almost $80 \%$ of the world population fully depends on medicinal plants for meeting their health care needs [1]. Bioactive compounds extracted from medicinal plants contain many organic compounds which provide definite physiological action in our body. For an example, phenols and flavonoids isolated from medicinal plants are reported to have positive impact on health and cancer prevention [2].Antioxidants are the chemicals that can prevent or slower cell damage. They have important preventive roles in changing the flavour and nutritional quality of food. They also prevent illness such as different types of cancers, cardiovascular and neurological diseases etc. Polyphenols are the most significant compounds for antioxidant properties of the plant raw material [3-5]. Plant mainly uses alpha amylase inhibition property to protect themselves from insect. They follow the mechanism of changing digestive property of alpha amylases and proteinases in the gut of insects resulting in abnormal feeding behaviour $[3,6]$. Diabetes is a clinical condition recognised by high level of glucose accumulated in the blood as cell does not respond to the insulin that is secreted by pancreas. Compounds like metformin, gliclazides, glitazones/vitagliptin/saxagliptin etc are predominantly supplied to patient to control the blood glucose level. Hence, plants with alpha amylase inhibition property are always very crucial as there are always needs for new source of antidiabetic molecule [7-8]. Allium species belongs to the family Liliaceae. It is the plant which is the native of China and Japan. Many natural products have been produced from this genus as they are used to cure tumor, cardiovascular 


\section{Indo Global Journal of Pharmaceutical Sciences, 2021; 11(1): 56-61}

disease, thrombosis, cholesterolmia and hyperglycemia [9-12]. Allium odorum is a small annual plant with leaves that are small, green, grass-like, narrowly linear, and flattish. Seeds are black, depressed, globose or uniform. Fruits are capsule that open longitudinally along the capsule wall between the partitions of the locule $[11,13]$.

\section{MATERIALS AND METHODS}

\section{Sample collection and sample preparation}

Leaves of A. odorum were collected from Imphal East District of Manipur in the month of March 2017 and was identified based on its vernacular name. The leaves were rinsed with tap water followed by distilled water and dried in the shade. The dried samples were grinded into the fine powder with the help of a grinder and kept in an air tight container for further use.

\section{Sample preparation}

An amount of 200 grams of dried powder was placed in Soxhlet apparatus for extraction using ethanol as solvent. The solvent was then evaporated and crude extract were collected for further use [3]. In another setup, an amount of 200 grams of fine powder $\mathrm{f}$ the sample were mixed in cold water an kept in deep freezer for $72 \mathrm{hr}$ and centrifuge at $3000 \mathrm{rpm}$. Solvent free crude were collected for further investigation [14].

\section{Screening for Phytochemicals [15-20]}

The crude extract was screened for the presence of different bioactive compounds. $20 \mathrm{mg} / \mathrm{mL}$ solvent concentration of the crude extract was prepared and further used for the tests

\section{Test for sterol}

Salkowski test- The crude extract (100mg) was shaken with chloroform $(2 \mathrm{~mL})$ followed by addition of concentrated sulphuric acid $(2 \mathrm{~mL})$ along the side of the test tube. Reddish brown colour development indicates the presence of sterol.

\section{Test for alkaloid}

Few $\mathrm{mg}$ about $(15 \mathrm{mg})$ of extract was stirred with $1 \% \mathrm{HCl}$ $(6 \mathrm{~mL})$ on water bath for $5 \mathrm{~min}$ and filtered.

a. Mayer`s test- To a portion of filtrate, Mayer`s reagent (potassium mercuric iodide solution) ( $1 \mathrm{~mL}$ ) was added. Cream colour precipitation indicates the presence of alkaloid.

b. Wagner`s test- Potassium iodide ( $2 \mathrm{~g}$ ) and iodine ( $1.27 \mathrm{~g}$ ) were dissolved in distilled water $(5 \mathrm{~mL})$ and the solution was diluted to $100 \mathrm{~mL}$ distilled water. Few drops of this solution were added to the filtrate. Brown colour precipitation indicates the presence of alkaloid.

\section{Test for tannins}

The extract was stirred with distilled water $(10 \mathrm{~mL})$ and filter. A few drops of $5 \%$ ferric chloride were then added. Green colour development indicates the presence of tannins.

\section{Test for flavonoid}

a. Alkaline reagent test- The crude extract was treated with few drops of sodium hydroxide solution. Formation of intense yellow, which become colourless on addition dilute acid indicates the presence of flavonoids. b. Sulphuric acid test- A fraction of extract was treated with concentrated sulphuric acid. Appearance of orange colour indicates the presence of flavonoid.

c. Lead acetate test- A small amount of extract was treated with lead acetate.

\section{Test for saponin}

A few $\mathrm{mg}$ of the test residue was diluted with distilled water in a test tube and shaken vigorously and heated in a water bath for $5 \mathrm{~min}$. Development of frothing indicates the presence of saponin.

\section{Test for glycoside}

Anthraquinone glycoside (Borntrager`s test )- The extract solution is boiled with dilute sulphuric acid, filtered and to the filtrate chloroform was added and shaken well. The organic layer is separated to which ammonia is added.

Development of red colour of the ammonical layer indicates the presence of glycoside.

Cardiac glycoside (Keller-Killiani test)- Extract $(0.5 \mathrm{~g})$ was shaken with distilled water $(5 \mathrm{~mL})$. To this glacial acetic acid $(2 \mathrm{~mL})$ containing a few drops of ferric chloride was added followed by sulphuric acid $(1 \mathrm{~mL})$ along the side of the test tube. Formation of ring at the interface gives positive result.

\section{Test for diterpenes}

Extract was dissolved in water and treated with 3-4 drops of copper acetate solution.

Appearance of ceramal green colour indicates the presence of diterpenes.

\section{Test for protein}

a. Biuret test- A few $\mathrm{mg}$ of the residue was taken in water and $1 \mathrm{~mL}$ of $4 \%$ copper sulphate was added to it. Violet ring development indicates the presence of protein.

b. Xanthoproteic test- A little residue was taken with $2 \mathrm{~mL}$ of water and $0.5 \mathrm{~mL}$ of concentrated nitric acid was added to it. Yellow colour development indicates the presence of protein.

\section{Test for amino acid}

Ninhydrin test- The ninhydrin reagent is $0.1 \% \mathrm{w} / \mathrm{v}$ solution of ninhydrin in n-butanol. A little of this reagent was added to the test extract. Development of violet colour indicates the presence of amino acid.

\section{Test for sugar}

a. Molisch test- A few mg of the test extract was placed in the test tube containing $.5 \mathrm{~mL}$ of water and it was mixed with $2 \mathrm{~mL}$ of concentrated sulphuric acid added from the side of the inclined test tube so that the acid formed a layer beneath the aqueous solution without mixing. Development of violet ring indicates the presence of sugar. 


\section{Indo Global Journal of Pharmaceutical Sciences, 2021; 11(1): 56-61}

b. Barfoed test- The reagent was prepared by dissolving $13.3 \mathrm{~g}$ of crystalline neutral copper acetate in $200 \mathrm{~mL}$ of $1 \%$ acetic acid solution The test residue was dissolved in water and heated with a little of the reagent. Green colour development indicates the presence of sugar.

\section{Test for phenol}

Extract was treated with 3-4 drops of $10 \%$ ferric chloride solution. Formation of bluish black colour indicates the presence of phenol.

\section{Alpha-amylase Inhibition Activity [21,22]}

A quantity of $0.1 \mathrm{~g}$ of starch was dissolved in $100 \mathrm{~mL}$ of acetate buffer $(16 \mathrm{mM})$ to prepare $0.1 \%$ starch solution. Similarly, $27.5 \mathrm{mg}$ of alpha amylase was dissolved in $100 \mathrm{~mL}$ of distilled water to prepare the enzyme solution. Sodium potassium tartarate solution and 3,5 dinitro salicylic acid solution at 96 $\mathrm{mM}$ were mixed to prepare the colorimetric reagent. Different concentration $(200,400,600,800,1000 \mu \mathrm{g} / \mathrm{mL})$ of extract were placed in different test tubes. To each test tube starch $(1 \mathrm{~mL})$, amylase $(1 \mathrm{~mL})$ was added and incubated for $15 \mathrm{mins}$. After incubation DNS $(1 \mathrm{~mL})$ was added and heated at $100^{\circ} \mathrm{C}$ and observed the colour change. The absorbance was taken at $540 \mathrm{~nm}$ against a blank. The percentage of $\alpha$-amylase inhibition was calculated using

$$
\text { \%Inhibition }=\frac{A_{\text {Control }}-A_{\text {sample }}}{A_{\text {control }}} \times 100
$$

\section{Antioxidant Assay $(23,24,25)$ \\ DPPH Method}

The antioxidant activity of ethanol and water extracts of the plant extract were assayed according to the standard method with slight modification. DPPH (2,2-diphenyl picryl hydrazyl) is composed of stable free radical molecules and is purple in colour. The antioxidant molecules (present in the test sample) react with DPPH and after the incubation time, the purple colour gets converted to yellow colour. Stock of the plant sample was made by dissolving $1 \mathrm{mg}$ of sample in $1 \mathrm{~mL}$ of distilled water. The absorbance was taken at 540nm against suitable blank using Ascorbic acid as a standard.

\section{$\mathrm{H}_{2} \mathrm{O}_{2}$ Method}

A concentration of $40 \mathrm{mM}$ hydrogen peroxide was prepared in phosphate buffer of $\mathrm{pH}$ 7.4. Different concentration of samples and distilled water were added to $\mathrm{H}_{2} \mathrm{O}_{2}(0.6 \mathrm{~mL}$, $40 \mathrm{mM}$ ). The absorbance was taken at $230 \mathrm{~nm}$ against a blank using Ascorbic acid as a standard. In both cases percentage of scavenging activity was calculated using the following equation:

$$
\% \text { Inhibition }=\frac{A_{\text {Control }}-A_{\text {sample }}}{A_{\text {Control }}} \times 100
$$

\section{Determination of Total Phenolic Content $(\mathbf{2 5}, 26)$}

Phenolic content is determined by Folin Ciocalteu method. An aliquot of $0.5 \mathrm{~mL}$ of extract $(1 \mathrm{mg} / \mathrm{mL})$ was mixed with $2.5 \mathrm{~mL}$ Fc reagent (previously diluted with distilled water 1:10) and $2 \mathrm{~mL}(75 \%)$ of $\mathrm{Na}_{2} \mathrm{CO}_{3}$. The tubes were vortex for $15 \mathrm{sec}$ and allowed to stand for $30 \mathrm{~min}$ at $40^{\circ} \mathrm{C}$ for colour development.
Absorbance was then measured at $765 \mathrm{~nm}$. Results were expressed as mg gallic acid equivalents (GAE)/g sample.

\section{Statistical analysis}

Bioactive activity namely antioxidant and $\alpha$-amylase inhibition activity for both the extracts were expressed as mean \pm standard deviation (SD) of three replicates with the help of software.

\section{RESULT AND DISCUSSION}

\section{Phytochemical Screening}

The plant medicinal value relies in the active phytochemicals that generates certain physiological impact on humans. A study on Allium sativum showed the rich presence of alkaloids, reducing sugar, flavonoids, glycosides, cardiac glycosides, tannin and phenolic compounds, saponins, amino acid \& triterpenoids in aqueous and methanolic extract of garlic leaves [27]. In the present study, the phytochemical screening of crude extract of Allium odorum also revealed the presence of various secondary metabolites. Water extracts showed the presence of sterol, tannin, saponin, diterpenes, sugars, flavonoids, whereas ethanol extract showed positive results for sterol, tannin, saponin, glycoside, diterpenes, amino acids, sugars and phenol. Alkaloid was absent in both ethanol and water extract (Table 1). Therefore, the presence or absence of such compounds depend largely on the extent of accumulation, the amount of plant material used and the analytical method employed

TABLE 1: Result of Phytochemical screening for both the extracts.

\begin{tabular}{|c|c|c|c|}
\hline \multirow{2}{*}{$\begin{array}{c}\text { SL. } \\
\text { NO. }\end{array}$} & \multirow{2}{*}{ PHYTOCHEMICALS } & \multicolumn{2}{|c|}{ RESULTS } \\
\cline { 3 - 4 } & & ETHANOL & WATER \\
\hline 1 & Sterol & $+\mathrm{ve}$ & $+\mathrm{ve}$ \\
\hline 2 & Alkaloid & $-\mathrm{ve}$ & $-\mathrm{ve}$ \\
\hline 3 & Tannin & $+\mathrm{ve}$ & $+\mathrm{ve}$ \\
\hline 4 & Flavonoid & $+\mathrm{ve}$ & $+\mathrm{ve}$ \\
\hline 5 & Saponin & $+\mathrm{ve}$ & $+\mathrm{ve}$ \\
\hline 6 & Glycoside & $+\mathrm{ve}$ & $-\mathrm{ve}$ \\
\hline 7 & Diterpenes & $+\mathrm{ve}$ & $+\mathrm{ve}$ \\
\hline 8 & Amino acid & $+\mathrm{ve}$ & $-\mathrm{ve}$ \\
\hline 9 & Sugar & $+\mathrm{ve}$ & $+\mathrm{ve}$ \\
\hline 10 & Phenol & $+\mathrm{ve}$ & $-\mathrm{ve}$ \\
\hline
\end{tabular}

$+=$ present; $-\mathrm{ve}=$ absent

In vitro alpha amylase inhibition activity

Although there are reports of alpha amylase inhibitory activity for six Allium species [28], very few reports are available for A.odorum in Manipur. In our present study, both the extracts showed an increase in dose dependent concentration with inhibition activity of $89.27 \%$ at $1000 \mu \mathrm{g} / \mathrm{mL}$ and $69.79 \%$ at $1000 \mu \mathrm{g} / \mathrm{mL}$ for ethanol and water extracts respectively, which is quite strong as compared to the results of [28]. A positive control was maintained and percentage of inhibition for both the extracts were tabulated (Table 2). The $\mathrm{IC}_{50}$ values for 
Indo Global Journal of Pharmaceutical Sciences, 2021; 11(1): 56-61

ethanol and water extract was found to be $253.63 \mu \mathrm{g} / \mathrm{mL}$ and $575.10 \mu \mathrm{g} / \mathrm{mL}$ respectively.

\section{Antioxidant activity}

\section{Antioxidant activity by DPPH Method}

The extracts showed noticeable antioxidant activity through DPPH methods. Antioxidant value was found to be maximum $(84.85 \%)$ at $200 \mu \mathrm{g} / \mathrm{mL}$ which is quite effective as against the inhibition of $82.2 \%$ for $80 \%$ ethanolic garlic extract studied by [29]. $\mathrm{IC}_{50}$ value for ethanol and water extract was found to be $56.12 \mu \mathrm{g} / \mathrm{mL}$ and $143.86 \mu \mathrm{g} / \mathrm{mL}$ respectively. Ascorbic acid was used as a standard while a separate positive control was also maintained.
$\mathrm{H} 2 \mathrm{O} 2$ Method

$\mathrm{H}_{2} \mathrm{O}_{2}$ assay of $T$. zeylanicum extract exhibited a dosedependent hydrogen peroxide inhibition where methanolic extract possessed good ability of scavenging with $\mathrm{IC}_{50}$ values $0.122 \mathrm{mg} / \mathrm{ml}$ [30]. But our study with A.odorum showed good scavenging ability with ethanolic extract. $\mathrm{IC}_{50}$ value for ethanol and water extract was found to be $73.08 \mu \mathrm{g} / \mathrm{mL}$ and $115.95 \mu \mathrm{g} / \mathrm{mL}$ respectively. Ascorbic acid was used as a standard while a separate positive control was also maintained.

TABLE 2: $\alpha$-Amylase inhibition activity for both the extracts.

\begin{tabular}{|c|c|c|c|c|c|c|c|}
\hline \multirow[b]{2}{*}{$\begin{array}{l}\text { Sl. } \\
\text { No. }\end{array}$} & \multirow[b]{2}{*}{$\begin{array}{c}\text { Conc. Of } \\
\text { sample } \\
(\mu \mathrm{g} / \mathrm{mL})\end{array}$} & \multicolumn{2}{|c|}{ Ethanol } & \multirow[b]{2}{*}{$\begin{array}{c}\mathrm{IC}_{50} \text { value } \\
(\mu \mathrm{g} / \mathrm{mL})\end{array}$} & \multicolumn{2}{|c|}{ Water } & \multirow[b]{2}{*}{$\begin{array}{l}\text { IC } 50 \text { value } \\
(\mu \mathrm{g} / \mathrm{mL})\end{array}$} \\
\hline & & $\begin{array}{c}\text { Absorbance } \\
\\
(\text { Values } \\
\text { represent } \\
\text { mean } \pm \text { SD, } n=3 \text { ) }\end{array}$ & $\begin{array}{c}\% \\
\text { inhibition }\end{array}$ & & $\begin{array}{c}\text { Absorbance } \\
\\
(\text { Values } \\
\text { represent } \\
\text { mean } \pm S D, n=3 \text { ) }\end{array}$ & $\begin{array}{c}\% \\
\text { inhibition }\end{array}$ & \\
\hline 1 & 200 & $0.266 \pm 0.57$ & 45.15 & \multirow{5}{*}{253.63} & $0.517 \pm 0.56$ & 33.54 & \multirow{5}{*}{575.10} \\
\hline 2 & 400 & $0.201 \pm 0.55$ & 58.55 & & $0.473 \pm 0.48$ & 39.20 & \\
\hline 3 & 600 & $0.136 \pm 0.55$ & 72.16 & & $0.368 \pm 0.50$ & 52.69 & \\
\hline 4 & 800 & $0.094 \pm 0.51$ & 80.61 & & $0.305 \pm 0.52$ & 60.79 & \\
\hline 5 & 1000 & $0.052 \pm 0.53$ & 89.27 & & $0.235 \pm 0.52$ & 69.79 & \\
\hline
\end{tabular}

TABLE 3: Antioxidant activity by DPPH method.

\begin{tabular}{|c|c|c|c|c|c|c|c|}
\hline \multirow[b]{2}{*}{$\begin{array}{l}\text { Sl. } \\
\text { No. }\end{array}$} & \multirow[b]{2}{*}{$\begin{array}{c}\text { Conc. Of } \\
\text { sample } \\
(\mu \mathrm{g} / \mathrm{mL})\end{array}$} & \multicolumn{2}{|c|}{ Ethanol } & \multirow[b]{2}{*}{$\begin{array}{c}\text { IC }_{50} \text { value } \\
(\mu \mathrm{g} / \mathrm{mL})\end{array}$} & \multicolumn{2}{|c|}{ Water } & \multirow[b]{2}{*}{$\begin{array}{l}\text { IC }_{50} \text { value } \\
(\mu \mathrm{g} / \mathrm{mL})\end{array}$} \\
\hline & & $\begin{array}{c}\text { Absorbance } \\
\text { (Values } \\
\text { represent } \\
\text { mean } \pm S D \\
n=3 \text { ) }\end{array}$ & $\begin{array}{c}\% \\
\text { inhibition }\end{array}$ & & $\begin{array}{c}\text { Absorbance } \\
\text { (Values } \\
\text { represent } \\
\text { mean } \pm \text { SD } \\
n=3)\end{array}$ & $\begin{array}{c}\% \\
\text { inhibition }\end{array}$ & \\
\hline 1 & 50 & $0.211 \pm 0.80$ & 49.27 & \multirow{4}{*}{56.12} & $0.324 \pm 0.72$ & 24.29 & \multirow{4}{*}{143.86} \\
\hline 2 & 100 & $0.154 \pm 0.86$ & 62.98 & & $0.267 \pm 0.76$ & 37.61 & \\
\hline 3 & 150 & $0.100 \pm 0.93$ & 75.96 & & $0.207 \pm 0.77$ & 51.63 & \\
\hline 4 & 200 & $0.063 \pm 0.87$ & 84.85 & & $0.146 \pm 0.84$ & 65.88 & \\
\hline
\end{tabular}

TABLE 4: Antioxidant activity by $\mathrm{H}_{2} \mathrm{O}_{2}$ Method.

\begin{tabular}{|c|c|c|c|c|c|c|c|}
\hline \multirow[b]{2}{*}{$\begin{array}{l}\text { Sl. } \\
\text { No. }\end{array}$} & \multirow[b]{2}{*}{$\begin{array}{l}\text { Conc. Of } \\
\text { sample } \\
(\mu \mathrm{g} / \mathrm{mL})\end{array}$} & \multicolumn{2}{|c|}{ Ethanol } & \multirow[b]{2}{*}{$\begin{array}{l}\text { IC }_{50} \text { value } \\
(\mu \mathrm{g} / \mathrm{mL})\end{array}$} & \multicolumn{2}{|c|}{ Water } & \multirow[b]{2}{*}{$\begin{array}{l}\mathrm{IC}_{50} \text { value } \\
(\mu \mathrm{g} / \mathrm{mL})\end{array}$} \\
\hline & & $\begin{array}{c}\text { Absorbance } \\
\\
\text { (Values } \\
\text { represent } \\
\text { mean } \pm \text { SD, } n=3 \text { ) }\end{array}$ & $\%$ inhibition & & $\begin{array}{c}\text { Absorbance } \\
\qquad \begin{array}{c}\text { Values } \\
\text { represent } \\
\text { mean } \pm \text { SD, } \\
n=3)\end{array}\end{array}$ & $\begin{array}{l}\% \\
\text { inhibition }\end{array}$ & \\
\hline 1 & 50 & $0.343 \pm 0.13$ & 47.55 & \multirow{4}{*}{73.08} & $0.533 \pm 0.18$ & 40.11 & \multirow{4}{*}{115.95} \\
\hline 2 & 100 & $0.303 \pm 0.18$ & 53.66 & & $0.427 \pm 0.23$ & 52.02 & \\
\hline 3 & 150 & $0.254 \pm 0.14$ & 61.16 & & $0.410 \pm 0.20$ & 53.93 & \\
\hline 4 & 200 & $0.211 \pm 0.16$ & 67.73 & & $0.375 \pm 0.24$ & 57.97 & \\
\hline
\end{tabular}




\section{Indo Global Journal of Pharmaceutical Sciences, 2021; 11(1): 56-61}

\section{Determination of phenolic content}

Total phenolic content was examined for the ethanol extract. Plant rich in phenolic compounds exhibit antioxidant property through redox properties. The ethanol extract showed 30.12 $\mathrm{mg}$ of GAE/g. Higher phenolic content showed better bioactivity. Therefore, the better antioxidant result may be due to this high phenolic content. Our results correlate with the study done by [31] that also revealed the ethanol extract to exhibit highest phenolic content compared to other extracts.

Medicinal plants are of great importance to the health care system. Plants such as vegetables, fruit, spices, etc have been used and have been continuously screened for new molecules with medicinal value. Even though many synthetic drugs are readily available, people prefer traditional folk medicine because of their lesser side effects.

\section{CONCLUSION}

The present investigation revealed that this plant contain bioactive compound which could be used for several purpose. The sample was found to exhibit a maximum of $89.27 \%$ and $69.79 \%$ of $\alpha$-amylase inhibition activity in ethanol and water respectively. The sample showed a maximum of $84.85 \%$ by DPPH method and $67.73 \%$ by $\mathrm{H}_{2} \mathrm{O}_{2}$ method of antioxidant property in ethanol extract. Comparing the results of ethanol extract with aqueous extract, ethanol extract possessed better bioactive activities. The results from the present study indicate that Allium odorum possessing antioxidant properties could serve as free radicals inhibitor or scavenger and can also be established as a potent anti-diabetic drug in future though animal modelling is required.

\section{ACKNOWLEDGEMENT}

The authors thank the management of Assam down town University, for providing all the necessary facilities in completing the work.

\section{CONFLICT OF INTEREST}

The authors declare no conflicts of interest.

\section{FUNDING SOURCE}

\section{NIL}

\section{DATA AVAILABILITY}

Not declared.

\section{REFERENCES}

1. Ganesan A, Marichamy K, Thagamariappan J. Development of Medicinal Plants Sector in India -An Empirical Study. International Journal of Engineering Technology, Management and Applied Sciences. 2016;4(1):81-8.

2. R V, RH L. Phytochemicals in diets for breast cancer prevention-the importance of resveratrol and ursolic acid. Food Sci Hum Wellness. 2012;1:1-13.

3. Talukdar N, Dutta A, Chakraborty R, Das K. Screening of phytochemicals, antioxidant and inhibitory effect on alphaamylase by ethanolic extract of Elaeocarpus ganitrus (Bark).
International Journal of Pharmaceutical Sciences and Research. 2017;8(12):5270-5.

4. Khongsai, M S, H SPK. Ethnomedicinal plants used by different tribes of Arunachal Pradesh Indian Journal of Traditional Knowledge 2011;10 (3):541-6

5. Mondal P, Bhuyan N, Das S, Kumar M, Borah S, Mahato K. Herbal Medicines Useful for the Treatment of Diabetes in North-East India: A Review. International Journal of Pharmacy and Biological Sciences. 2013;3(1):575-89.

6. Wickramaratne MN, Punchihewa JC, Wickramaratne DBM. Invitro alpha amylase inhibitory activity of the leaf extracts of Adenanthera pavonina. BMC Complementary and Alternative Medicine 2016:1-5.

7. Alamin MA, Yagi AI, Yagi SM. Evaluation of antidiabetic activity of plants used in Western Sudan. Asian Pacific Journal of Tropical Biomedicine. 2015;5(5):395-402.

8. Barman I, Barman K, Purohit MM, Choudhury M, Choudhury AK, Choudhury MK. A study of mental stress and antioxidant profile in the Assamese-speaking diabetic population of Assam, India. International Journal of Diabetes in Developing Countries. 2015;35(2):163-72.

9. Shi J, Liu X, Li Z, Zheng Y, Zhang Q, Liu X. Laboratory Evaluation of Acute Toxicity of the Essential Oil of Allium tuberosum Leaves and Its Selected Major Constituents Against Apolygus lucorum (Hemiptera: Miridae). J Insect Sci. 2015;15(1): 117

10. Ikram R, Low KH, Hashim NB, Ahmad W, Nasharuddin MNA. Characterization of Sulfur-Compounds as Chemotaxonomic Markers in the Essential Oils of Allium Species by Solvent-Free Microwave Extraction and Gas Chromatography-Mass Spectrometry. Analytical Letters. 2019;52(4):563-74.

11. R PT, S P, A P, ST P. Pleiotropic Garlic (Allium Sativum) in the Treatment of Diabetes Mellitus and its Complications. International Journal of Pharmacognosy and Phytochemical Research 2016;8(7):1227-37.

12. Ryu R, Jung UJ, Seo Y-R, Kim H-J, Moon BS, Bae J-S, et al. Beneficial effect of persimmon leaves and bioactive compounds on thrombosis. Food Science and Biotechnology. 2015;24(1):233-40.

13. Borborah K, Dutta B, Borthakur SK. Traditional Uses of Allium L. Species from North East India with Special Reference to their Pharmacological Activities. American Journal of Phytomedicine and Clinical Therapeutics.2014:8(2):1037-51.

14. NN A. A Review on the Extraction Methods Use in Medicinal Plants, Principle, Strength and Limitation. Medicinal \& Aromatic Plants. 2015;4(3):1-6.

15. Saeed N, Khan MR, Shabbir M. Antioxidant activity, total phenolic and total flavonoid contents of whole plant extracts Torilis leptophylla L. BMC Complement Altern Med. 2012;12:221.

16. Al-Rimawi F, Rishmawi S, Ariqat SH, Khalid MF, Warad I, Salah Z. Anticancer Activity, Antioxidant Activity, and Phenolic and Flavonoids Content of Wild Tragopogon porrifolius Plant Extracts. Evidence-Based Complementary and Alternative Medicine. 2016:1-7.

17. Dogra NK. Phytochemical Analysis and In vitro Antioxidant Studies of Plumeria obtusa L. Leave. Indian Journal of Pharmaceutical Sciences. 2016;78(1):169-71.

18. Khan A, Anand V, Badrinarayanan V, Thirunethiran K, Natarajan P. In vitro Antioxidant and Cytotoxicity Analysis of Leaves of Ficus racemosa. Free Radicals and Antioxidants. 2017;7(1):8-12.

19. Dechayont B, Ruamdee P, Poonnaimuang S, Mokmued K, Chunthorng-Orn J. Antioxidant and antimicrobial activities of 
Indo Global Journal of Pharmaceutical Sciences, 2021; 11(1): 56-61

Pogostemon cablin (Blanco) Benth. Journal of Botany. 2017:16.

20. Yadav BS, Yadav R, Yadav RB, Garg M. Antioxidant activity of various extracts of selected gourd vegetables. J Food Sci Technol. 2016;53(4):1823-33.

21. Mirshafie B, Mokhber-Dezfouli N, Manayi A, Saeidnia S, Ajani Y, Gohari AR. Alpha-amylase inhibitory activity and phytochemical study of Zhumeria majdae Rech. f. and Wendelbo. Pharmacognosy Res. 2014;7(4):309-13.

22. Tamil IG, Dineshkumar B, Nandhakumar M, Senthilkumar M, Mitra A. In vitro study on $\alpha$-amylase inhibitory activity of an Indian medicinal plant, Phyllanthus amarus. Indian J Pharmacol. 2010;42(5):280-2.

23. Mahdi-Pour B, Jothy SL, Latha LY, Chen Y, Sasidharan S. Antioxidant activity of methanol extracts of different parts of Lantana camara. Asian Pac J Trop Biomed. 2012;2(12):960-5.

24. Ashafa AOT, Grierson DS, Afolayan AJ. In vitro antioxidant activity of extracts from the leaves of Felicia muricata thunb. An underutilized medicinal plant in the Eastern Cape Province, South Africa. Afr J Tradit Complement Altern Med. 2010;7(4):296-302.

25. Ulewicz-Magulska B, Wesolowski M. Total Phenolic Contents and Antioxidant Potential of Herbs Used for Medical and Culinary Purposes. Plant Foods Hum Nutr. 2019;74(1):61-7.

26. Aryal S, Baniya MK, Danekhu K, Kunwar P, Gurung R, Koirala N. Total Phenolic Content, Flavonoid Content and Antioxidant Potential of Wild Vegetables from Western Nepal. Plants (Basel). 2019;8(4):96.

27. Singh V, Kumar R. Study of Phytochemical Analysis and Antioxidant Activity of Allium sativum of Bundelkhand Region. Int. J. Life. Sci. Scienti. Res. 2017: 3(6):1451-1458.

28. Nickavar B, Yousefian N. Inhibitory Effects of Six Allium Species on $\alpha$-Amylase Enzyme Activity. Iran. J. Pharm. Sci.2009: 8 (1): 53-57

29. Qadir MA, Shahzadi SK, Bashir A, Munir A, Shahzad S. Evaluation of Phenolic Compounds and Antioxidant and Antimicrobial Activities of Some Common Herbs. Int. J. Anal. Chem.2017: 1-6.

30. Ngonda F. In- vitro Anti-oxidant Activity and Free Radical Scavenging Potential of roots of Malawian Trichodesma zeylanicumm (burm. f.). Asian j. biomed. Pharm.2013: 3(20):21-25.

31. Aydin C, Mammadov R. Phytochemical analysis, phenolic content, antioxidant, antibacterial, insecticidal and cytotoxic activites of Allium reuterianum Boiss. Extracts. Indian J. Tradit. Knowl.2019: 18(2): 290-298

Indo Global Journal of Pharmaceutical Sciences( ISSN 2249 1023; CODEN- IGJPAI; NLM ID: 101610675) indexed and abstracted in CrossRef (DOI Enabling), CNKI, EMBASE (Elsevier), National Library of Medicine (NLM) Catalog (NCBI), ResearchGate, Publons (Clarivate Analytics), CAS (ACS), Index Copernicus, Google Scholar and many more. For further details, visit http://iglobaljournal.com 